\title{
MORBID OBESITY AS AN IMPORTANT MEDICAL PROBLEM OF THE 21ST CENTURY: ACUTE INTESTINAL OBSTRUCTION IN OBESE PATIENTS
}

\author{
Kolesnikov E. B., Kryzhevsky V. V.
}

\section{INTRODUCTION}

Obesity is a chronic genetically determined, multifactorial, lifethreatening disease caused by excessive accumulation of fat in the body, leading to serious medical, social and economic consequences. Obesity is rapidly spreading around the world. An analysis of recent data on European countries shows that $40-60 \%$ of the adult population are overweight and up to $25-30 \%$ are morbidly obese. In Europe, about 150 million people are overweight, and about 40 million are morbidly obese. In obese people, life expectancy decreases, and mortality rates under the age of 40 increased by 12 times ${ }^{1}$. The indicators of sudden unexplained death are significantly higher in patients with morbid obesity (MO) than in patients with normal body weight. Over $75 \%$ of type 2 diabetes cases are associated with a body mass index (BMI) of more than $25 \mathrm{~kg} / \mathrm{m}^{2}$.

\section{Morbid obesity in Ukraine}

In Ukraine only $44 \%$ of men and $25 \%$ of women have normal body weight ${ }^{3}$. According to A. Kaminsky in Ukraine $32 \%$ of women age of 20 to 29 years and $52 \%$ of people over 45 years old are overweight ${ }^{4}$. High Body Mass Index (BMI) with excess of body fat, the presence and severity of the metabolic syndrome determine the severity of the course of the disease, when combined with intestinal obstruction (ABO). This group of patients causes difficulties at all stages of diagnosis and medical care. Clinical manifestations are often hidden, due to the fact that the layer of fatty tissue of the anterior abdominal wall $(10-15 \mathrm{~cm})$ complicates the selection of

\footnotetext{
${ }^{1}$ Felsher J.Brodsky J., Brody F. Small bowel obstruction after laparoscopic Roux-enY gastric bypass. Surg. 2003; 134:501-5.

${ }^{2}$ Nguyen N.T., Huerta S., Gelfand D.et al. Bowel obstruction after laparoscopic Roux-en-Y gastric bypass. Obes. Surg., 2004;(14):190-196.

3 Луценко Н.С. Акушерские аспекты ожирения, Запорожье : Просвіта, 2000. $160 \mathrm{c}$.

4 Каминский А.В. Методы коррекции избыточной массы тела и ожирения. “Здоров’я України. № 112, II-2005 г. С. 34.
} 
modes when performing x-ray and ultrasound examinations, and prevents palpation of the abdominal organs during physical examination. During general anesthesia, difficulties are associated with the adsorption of lipophilic anesthetic drugs by adipose tissue with their primary deposition in it and subsequent release, which distorts the pharmacokinetics and pharmacodynamics, which may result in both insufficient effectiveness and overdose of anesthetic drugs, prolongation of the patient withdrawal stage anesthesia. All this requires a higher qualification of the anesthesiologist, careful accounting of injected fluids, recalculation of drug dosages and ventilation modes in connection with body mass index (BMI) ${ }^{5}$. The hypertrophied subcutaneous fat presents additional difficulties during performing surgery. In figure 1 shows a small Gastric Pouch (GP), created by using a linear stapler (shown by a dashed line); alimentary branch (shown by bold black arrows); passage of the contents of the stomach (shown by white arrows); stitched loop of the jejunum (curved arrow), or the closed end of the loop of the Roux-en-Y anastomosis and ejunojejunoanastomosis with bilio-pancreatic branch (thin black arrows) ${ }^{6}$.

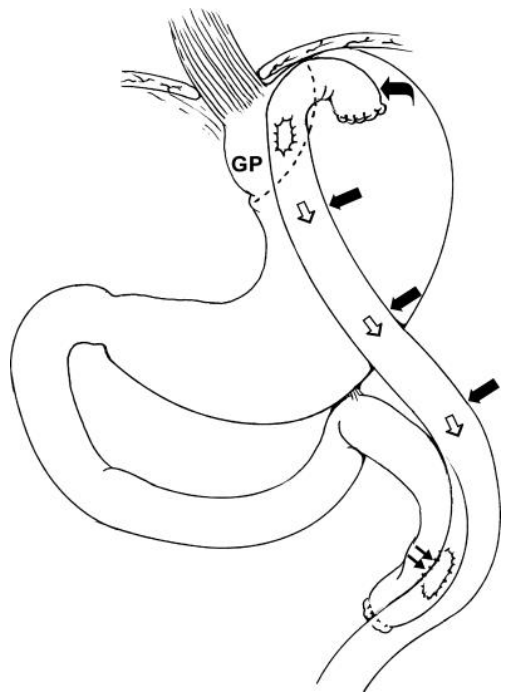

Fig. 1. Gastrointestinal bypass surgery with Roux-en-Y anastomosis ${ }^{7}$

\footnotetext{
${ }^{5}$ Cowan G, Hiller M. L., Martin L.F. Reoperative obesity surgery. In Obesity surgery, McGraw Hill Comp., 2004, P. 301-334.

${ }^{6}$ Yu J. et al. Roux-en-Y Gastric Bypass , Radiology 2004; (231): 753-760.

${ }^{7}$ Ibid.
} 
A proximal GP with a volume of $25-30 \mathrm{ml}$ is formed along the lesser curvature of the stomach so as to exclude the bottom and remaining stomach. The jejunum intersects at a level of $45-50 \mathrm{~cm}$ distal to the ligament of Treitz in order to create a bilio-pancreatic branch. Subsequently, an anastomosis is applied between the proximal GP and the distal crossed loop of the jejunum, which creates an alimentary branch. Next, an anastomosis is created between the bilio-pancreatic and alimentary branches at a distance of $\geq 100 \mathrm{~cm}$ distal to the gastroejunoanastomosis, with the formation of a common channel. Thus, most of the stomach, duodenum, and proximal jejunum are excluded from active alimentary activity.

\section{Acute bowel obstruction as dangerous postoperative complication after surgical treatment of morbid obesity}

Acute Bowel Obstruction (ABO) is one of the most common dangerous postoperative complications of the obesity surgery. In the patients, operated on for morbid obesity (bandages on the stomach, gastrointestinal bypass surgery, sleeve gastrectomy, etc.) conditions may arise for obstruction of the anastomoses and intestines in the early (up to 30 days) and long-term (after 30 days) postoperative periods. Postoperative acute intestinal obstruction occurs in $1-9 \%$ of cases ${ }^{8}$.

Adhesive etiology ABO may involve alimentary, bilio-pacreatic branches, a common canal, or more distal sections of the small intestine. In a relatively simplified classification $\mathrm{ABO}$ is divided into types according to the anatomical localization of obstruction after Roux-en-Y gastrointestinal Bypass (figure 2$)^{9}$.

The main causes of bowel obstruction in morbidly obese patients:

- pronounced obesity of internal organs (mesentery of the intestine, omentum, liver and other organs) can create significant difficulties in performing the bariatric operation;

- technical inaccuracies in the operation, leaving open the holes created in the mesentery of the intestine;

- kink of the intestine in the area of entero-entero anastomosis;

- obstruction of the anastomosis or small intestine with a large piece of food;

${ }^{8}$ Champion J.K., William M., Small bowel obstruction and internal hernias after laparoscopic Roux-en-Y gastric bypass. Obes surg. 2003; 13: 596-600.

Higa K.D., Ho T, Boone K.B. Internal hernias after laparoscopic Roux-en-Y gastric bypass: incidence, treatment and prevention. Obes Surg., 2003.

9 Tucker O.N, Escalante-Tattersfield T., Szomstein S., Rosenthal R. The ABC System: A Simplified Classification System for Small Bowel Obstruction After Laparoscopic Roux-en-Y Gastric Bypass Obesity Surgery 2007; (17): 1549-1554. 


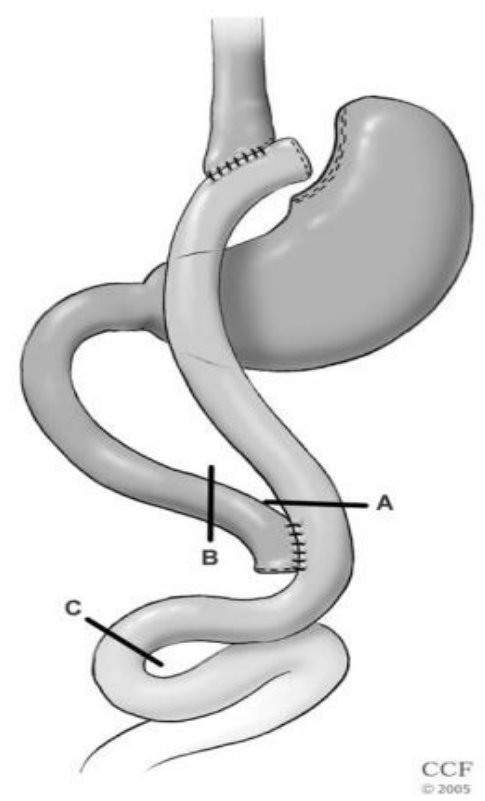

Fig. 2. Anatomical localization of obstruction after Roux-en-Y Gastrointestinal Bypass ${ }^{10}$ : A - obstruction of the alimentary branch; B - obstruction of the bilio-pacreatic branch; C - obstruction of the common canal

- hematoma and thrombosis in the area of entero-entero anastomosis;

- adhesive process in the abdominal cavity;

- the formation of internal hernias, postoperative hernias of the epigastric and other regions, etc.;

- intussusception and nodulation of the intestine;

- scarring in the area of the anastomosis with its stenosis;

- other causes of bowel obstruction.

A methodical approach helps identify the site of obstruction in most patients in the preoperative period. Although the symptoms often do not have a specific symptoms for a certain localization of obstruction, in some cases it can be assumed that the presence of gastroesophageal reflux and significant vomiting is associated with obstruction of the alimentary branch or common canal.

${ }^{10}$ Ukleja A., Stone R. L. Medical and gastroenterologic management of the postbariatric surgery patient. J Clin Gastroenterol 2004; 38(4): 312-21. 
En enlarged bilio-pancreatic branches and the distal part of the stomach with increased activity of the liver enzymes and hyperamilasemia associated with obstruction of the bilio-pancreatic branch or common channel.

\section{Diagnostic studies in patients with $\mathrm{ABO}$ in morbidly obese patients}

Diagnosis of acute intestinal obstruction in patients with obesity can be extremely difficult, especially in the early postoperative period, when pain can still be perceived as ordinary postoperative pain. In addition, these patients may not have vomiting in the first days after surgery. Ultrasound examinations and computed tomography are difficult due to the low mobility of the patient and the thick anterior abdominal wall. Therefore, the occurrence of sharp pain in the periumbilical region, poorly stopping or not stopping with strong analgesics, up to narcotic drugs, nausea and lack of peristalsis should be regarded as a possible acute intestinal obstruction until its absence is proved.

G. Cowan et al. (2004) also indicates the possibility of repeated episodes of bowel obstruction in $2.5 \%$ of patients. The main cause of obstruction was adhesions of the intestine. In other patients, the cause of obstruction in the distant postoperative period was a change in thickness and lengthening of the mesentery after weight loss, which created the conditions for torsion and nodulation of the intestine. In 2 cases, invagination of the small intestine was observed $^{11}$.

One of the causes of early $\mathrm{ABO}$ is the occurrence of internal hernias. Internal hernias in their development are more characteristic as complications of minimally invasive bariatric operations. The frequency of their occurrence is approximately $3-5 \%$ with laparoscopic ${ }^{12}$ and $1.3-4.5 \%$ with open techniques ${ }^{13}$ (figure 3 ).

A. Gumbs et al. (2006) from Yale University (USA) also showed the occurrence of obstruction of the jejunojejunal anastomosis after laparoscopic bariatric surgery in $4.6 \%$ of cases ${ }^{14}$.

The cause of acute obstruction was the formation of adhesions near the anastomosis after closing the mesenteric defect with a non-absorbable

${ }^{11}$ Cowan G, Hiller M. L., Martin L.F. Reoperative obesity surgery. In Obesity surgery, McGraw Hill Comp., 2004. P. 301-334.

${ }_{12}$ Champion J.K., William M., Small bowel obstruction and internal hernias after laparoscopic Roux-en-Y gastric bypass. Obes surg. 2003; 13: 596-600.

${ }^{13}$ Higa K.D., Ho T, Boone K.B. Internal hernias after laparoscopic Roux-en-Y gastric bypass: incidence, treatment and prevention. Obes Surg., 2003; 13: 350-4.

14 Gumbs A.A., Duffy A.J., Chandwani R. et al. Jejuno-jejunal anastomotic obstruction following laparoscopic gastric bypass due to non-absorbable suture: a report of seven cases. Obes. Surg. 2006;16: 12-15. 
suture. In the next series of patients who used absorbable sutures in these cases, the formation of adhesive cords and intestinal obstruction in this zone were not observed ${ }^{15}$. The absolute necessity to close mesenteric defects was actively debated in the literature on surgery for obesity.

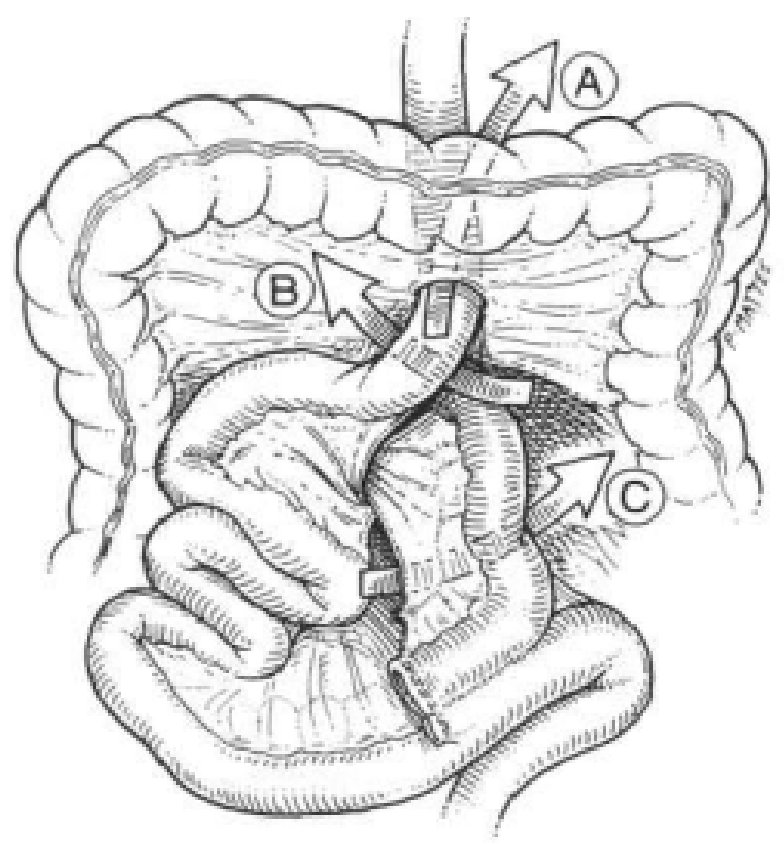

Fig. 3. Places of formation of internal hernias after bariatric surgery ${ }^{16}$ : $A$ - mesentery of the transverse colon $(67 \%) ; B$ - mesenteric defect of the jejunum (21\%); C - Petersen space (7.5\%) and others (restrained, ventral hernias $4.5 \%$ )

Some authors (A.K. Madan et al) claimed that after performing 387 laparoscopic surgeries, only 4 patients needed reoperation for an internal hernia. Therefore, there is no need to routinely close all mesenteric defects

${ }^{15}$ Madan A.K., Lo Menzo E, Dhawan N et al. Internal hernias and non-closure of mesenteric defects during laparoscopic Roux-en-Y gastric bypass. Obes Surg., 2009; 19(5):549-52.

${ }^{16}$ Higa K.D., Ho T, Boone K.B. Internal hernias after laparoscopic Roux-en-Y gastric bypass: incidence, treatment and prevention. Obes Surg., 2003; 13: 350-4. 
during surgery ${ }^{17}$. However, French scientists (E. Facchiano et al.) from the University of Paris argue that the possibility of damage to mesenteric vessels and the appearance of hematomas is greatly exaggerated. In addition, the price of suture material used for this is also low and there is no reason to talk about saving money spent on the operation. Therefore, it is better, nevertheless, to close the mesenteric defects during bariatric surgery and not to think subsequently whether or not the patient will have an internal hernia ${ }^{18}$.

According to studies conducted at the Bariatric Surgery Center in Rochester (USA), the most common symptoms of acute intestinal obstruction in patients who underwent laparoscopic gastrointestinal bypass surgery for obesity were: abdominal pain $(82.5 \%)$, followed by nausea $(48.6 \%)$ and vomiting (46.8\%). All three of these symptoms were noted in $27.9 \%$ of patients. The average time elapsed from bariatric surgery to the time of the first attack of pain was 313 days (from 3 to 1215 days).

Among instrumental diagnostic studies in this category of patients, only $48 \%$ of all performed CT scans, $55.4 \%$ of endoscopic procedures and $34.8 \%$ of abdominal radiographs were positive, indicating acute intestinal obstruction. In $13.5 \%$ of patients, all radiological findings were negative.

The most common causes of obstruction were internal hernias (53.9\%), compression of the Roux-branch of the small intestine into the mesacolon due to scarring (20.5\%), adhesions of the abdominal cavity (13.7\%). In $82 \%$ of cases, it was possible to eliminate intestinal obstruction using the laparoscopic method ${ }^{19}$.

A group of bariatric surgeons from the University of Atlanta (USA) showed that in their studies in $81 \%$ of cases, internal hernias were formed through Petersen space, 19\% through a defect in the mesentery of the colon and that the imposition of the Roux-en-Y anastomosis and the position of the loop of the small intestine counterclockwise to the left of the mesentery axis significantly reduces the possibility of the formation of internal hernias ${ }^{20}$, although not all researchers agree with this.

${ }^{17}$ Madan A.K., Lo Menzo E et al. Internal hernias, non-closure of mesenteric defects laparoscopic Roux-en-Y gastric bypass. Obes Surg., 2009; 19(5):549-52.

${ }^{18}$ Facchiano E., Iannelli A., Gugenheim J. Et al. Internal hernias and non-closure of mesenteric defects during laparoscopic Roux-en-Y gastric bypass. Obes Surg, 2010;20:676-678.

${ }^{19}$ Husain S, Ahmed AR, Johnson J, Boss T, O’Malley W Small-bowel obstruction after laparoscopic Roux-en-Y gastric bypass: etiology, diagnosis, and management. Arch Surg. 2007 Oct;142(10):988-93.

20 Nandipati KC, Lin E, Husain F, Srinivasan J, Sweeney JF, Davis SS. Counterclockwise rotation of Roux-en-Y limb significantly reduces internal herniation in laparoscopic Roux-en-Y gastric bypass (LRYGB). J Gastrointest Surg. 2012 Apr;16(4):675-81. Epub 2012 Feb 7. 
We (with D. Halmi and O. Anez) have created a mini-invasive method for performing Roux-en-Y Gastro-intestinal Bypass through minilaparotomy incision (about $8 \mathrm{~cm}$ ), which can significantly reduce the incidence of bowel obstruction (up to $0.8 \%$ ) by reducing bowel injury during surgery and less pronounced adhesions in the postoperative period. In the materials that we reported in 2004-6 at the XXXIV and XXXV World Congresses of the International College of Surgeons in Ecuado and Thailand, concerning the complications and difficulties in performing this operation, out of 500 operated patients, $4(0.8 \%)$ revealed intestinal obstruction Moreover, in 2 patients it occurred in the early postoperative period on 5 and 7 days. In both patients, the cause of obstruction was an excess of the abducting intestine in the region of the lower (entero-entero) anastomosis. Analyzing the causes of this complication, we began to make this anastomosis significantly wider using the stapler technique, with suturing and cutting the small intestine in two opposite directions. In addition, we began to impose a special suture that prevents bowel kinking in the area of the anastomosis. In the other 2 patients, bowel obstruction occurred in the distant postoperative period and was caused by adhesions in one and intestinal invagination in the second patient ${ }^{21}$.

Retrograde intestinal invagination is not a frequent complication in bariatric surgery, however, when this happens, more often in 1-1.5 years after bariatric surgery, then there are primarily difficulties in diagnosing this condition, which can lead to a delay in performing timely adequate surgical intervention ${ }^{22}$.

A similar case is also described in the literature, where the authors met with the same problems.

Diagnosis of this condition is difficult. In a complex of radiological studies, a pathognomonic symptom for intussusception can be detected: detection of the "gut in the gut" site. This pathology often occurs with rapid

${ }^{21}$ Halmi D., Anez O., Kolesnikov E. Mini-open roux-en-Y gastric bypass: surgical complications and difficulties. XXXIV World Congress of the International College of Surgeons, October 2004, Quito, Ecuador. International Proceedings, MEDIMOND, Italy, 2004, p. 109-11.

Halmi D, Anez O, Kolesnikov E Mini-open Roux-en-Y gastric bypass as the operation of choice for the majority of morbidly obese patients. Obesity surgery, 15, 2005, p. 960-6.

Tran D, Halmi D, Kolesnikov E Intussusception following roux-en-y gastric bypass : two case reports ans literature review , 14-th IFSO World Congress, August 26-29, 2009, Paris, France, Obesity Surgery, 19 (8) 2009, 1038-1039.

${ }^{22}$ Steeg K.V. Retrograde intussusception following Roux-en-Y gastric bypass Obes Surg. 2006;16: 1101-1103. 
weight loss and hyperactivity of intestinal motility. As a rule, in these patients, retrograde invagination occurs in the proximal part of the small intestine, in the so-called "common channel" (figures 4-6).

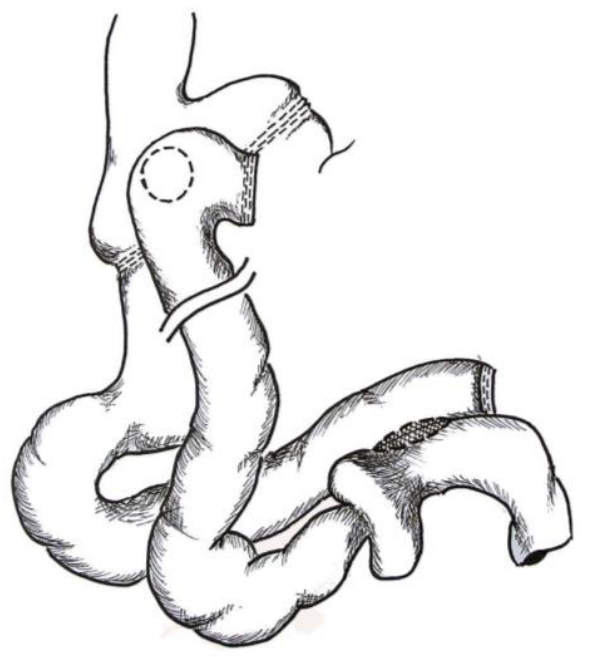

Fig. 4. Invagination of the small intestine in the area of entero-entero anastomosis after bariatric gastroejunal bypass surgery

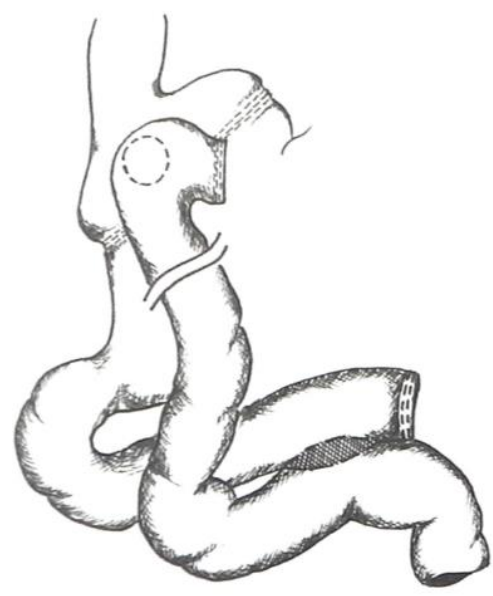

Fig. 5. Corrective surgery with re-entero-entero anastomosis after invagination of the small intestine after bariatric gastroejunal bypass 


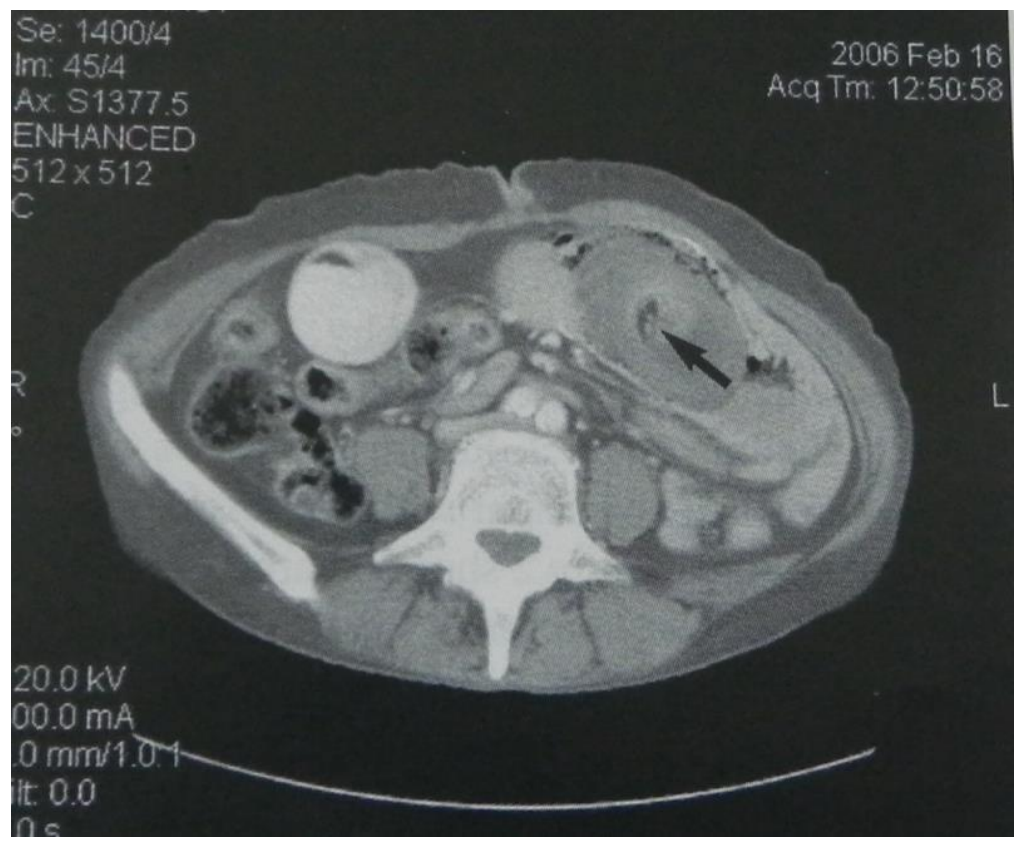

Fig. 6. Radiological symptom pathognomonic for intestinal invagination on CT "gut in the gut" (indicated by arrow) ${ }^{23}$

Case report: the patient T., 43 years old, a woman who underwent bariatric surgery 17 months ago - Mini-open Roux-en-Y Gastric Bypass, lost $64 \mathrm{~kg}$ of body weight and continued to lose weight. She noted an intestinal hyperactivity, periodically flatulence, nausea, non-intense abdominal pain for two months and intensified in the last two weeks. The patient was operated on. The damaged part of the small intestine was resected together with the entero-entero anastomosis (figure 4) and a new stapler entero-entero anastomosis was applied side-to-side (figure 5), drainage the abdominal cavity, nasogastric tube. The postoperative period without complications. Patient was discharged on the 4th day in a satisfactory condition.

The technique we described for applying stapler gastro-entero and entero-entero anastomoses allowed us to achieve good postoperative results - the absence of leakage in 1200 anastomoses when performing

${ }^{23}$ Steeg K.V. Retrograde intussusception following Roux-en-Y gastric bypass Obes Surg. 2006;16: 1101-1103. 
bariatric surgery in patients with morbid obesity. The results were reported at the 9th World IFSO Congress of Surgeons in Tokyo (2004) $)^{24}$.

An internal hernia in the Petersen's space does not occur too frequently in bariatric patients, but it has its own difficulties in diagnosing and performing surgical intervention to correct it.

This type of internal hernia was first described in 1900 by the German surgeon Walter Petersen ${ }^{25}$. Petersen's hernia can occur as a result of the introduction of a loop of the small intestine through a defect formed by the mesentery of the transverse colon, the mesentery of the loop of the small intestine and retroperitonium after almost any type of gastrojejunostomy, most often after the application of Roux-enY gastroenteroanastomosis. It is believed that this type of bowel obstruction can occur more often when performing bariatric operations using laparoscopic techniques ${ }^{26}$. One of the basic principles that must be observed in surgery for obesity is the closure of all defects of the mesentery of the intestine before closing the abdominal cavity. This will reduce the number of dangerous complications such as bowel obstruction in this category of patients.

The following reasons can lead to ABO: anastomotic strictures, bowel obstruction. anastomosites, adhesions, hematomas of the anastomotic region $^{27}$. Fig. 7 shows a large blood clot, that formed in the early postoperative period in the area of entero-entero anastomosis and, blocking it, caused acute intestinal obstruction ${ }^{28}$.

One of the options for surgical treatment of obstruction due to narrowing or blocking the area of entero-entero anastomosis is the imposition of bypass additional anastomoses, as shown in figure $8 \mathrm{~A}$ and $\mathrm{B}^{29}$.

${ }^{24}$ Halmi D., Anez O., Kolesnikov E., Roux -en-Y gastric bypass: gastro-jejunostomy technique and complications. Obesity Surgery, 16, (4) 2006, 404-405; $2^{\text {nd }}$ European IFSO Congress of Bariatric and Plastic Surgery, April 27-29, 2006, Lyon, France.

Halmi D., Anez O., Kolesnikov E. Mini-open Roux-en-Y gastric bypass: 1200 anastomoses without leak. Obesity Surgery, 14, 8, 2004, p. 900-901.

${ }^{25}$ Petersen W. Ueber darmveschlingung nach der gastro-enterostomie. Arch Klin Chir. 1900;62:94-114.

${ }^{26}$ Husain S, Ahmed AR, Johnson J, Boss T, O’Malley W Small-bowel obstruction after laparoscopic Roux-en-Y gastric bypass: etiology, diagnosis, and management. Arch Surg. 2007 Oct;142(10):988-93; Steeg K.V. Retrograde intussusception following Rouxen-Y gastric bypass Obes Surg. 2006;16: 1101-1103.

27 MacGregor AMC Small bowel obstruction following gastric bypass. Obes Surg., 1992; 2:333-9.

${ }^{28}$ Helling T.S. The Lethality of Obstructing Hematoma at the Jejunojejunostomy following Roux-en-Y Gastric Bypass. Obesity Surgery 2005; (15): 290-293.

${ }^{29}$ Nguyen N.T., Huerta S., Gelfand D.et al. Bowel obstruction after laparoscopic Roux-en-Y gastric bypass. Obes. Surg., 2004;(14):190-196 P. 16. 


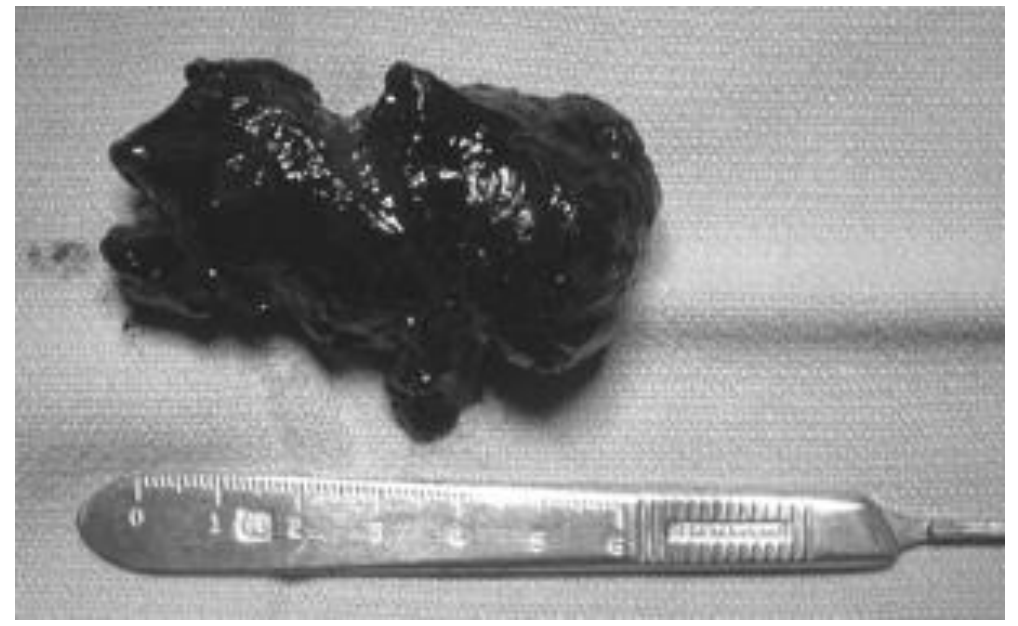

Fig. 7. A large blood clot formed in the area of the junior anastomosis and causing acute intestinal obstruction ${ }^{30}$

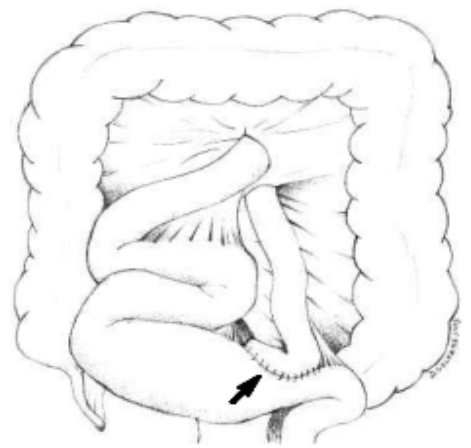

A

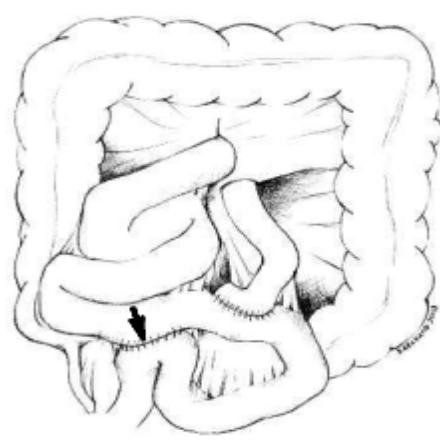

B

Fig. 8. Schematic representation of the anatomical site of the occurrence of $\mathrm{ABO}$ in the area of the jejunojejunostomy (black arrow) after ROUX-en-Y gastro-jejunal bypass (A) and schematic representation of the proximal entero-enterostomy (black arrow) in order to eliminate the $\mathrm{ABO}$ in the jejunojejunostomy $(\mathrm{B})^{31}$

${ }^{30}$ Helling T.S. The Lethality of Obstructing Hematoma at the Jejunojejunostomy following Roux-en-Y Gastric Bypass. Obesity Surgery 2005; (15): 290-293. P. 17.

${ }^{31}$ Nguyen N.T., Huerta S., Gelfand D.et al. Bowel obstruction after laparoscopic Roux-en-Y gastric bypass. Obes. Surg., 2004;(14):190-196. P. 18. 


\section{Some important aspects of anesthetic management and intensive care}

Before and during anesthesia, morbidly obese patients should undergo thorough laboratory and instrumental studies of the preoperative state of metabolism, electrolytes balance, functions of the vital organs with determination the risk of intra- and postoperative complications.

The features of surgical interventions and anesthesia in patients with severe pathological forms of obesity and $\mathrm{ABO}$ are: the need for surgery and general anesthesia in patients with metabolic syndrome, including diabetes mellitus, cardiovascular disorders, hypertension, often with anemia, an imbalance of vitamins and minerals, changes in liver, thyroid, and other syndromes, but for which bariatric surgery and weight loss are the only chance for survival.

When carrying out general anesthesia and operations for bowel obstruction in patients with obesity, it is also necessary to consider that:

- modification of all diagnostic and therapeutic algorithms may be necessary depending on BMI and clinical forms of pathological obesity. The use of standard diagnostic, radiological, ultrasound and other functional methods can be extremely difficult or impossible;

- changes in the calculation of narcotic drugs, muscle relaxants and other medications used to correct the electrolyte-electrolyte balance depending on BMI and the ratio of muscle and fat mass of the body are needed, as well as careful calculation of the medications administered, as both insufficient efficacy and drug overdose are possible;

- prolonged laparoscopic surgery in patients with obesity can lead to hemodynamic changes in the thoraco-abdominal zone, respiratory disorders and acidosis due to a prolonged increase in intra-abdominal pressure and diaphragm compression;

- lung ventilation during surgery should be fully adequate and sufficient during all periods of general anesthesia, as well as in the early postoperative period, using, if necessary, respiratory stabilization and resuscitation departments for prolonged mechanical ventilation that should be adjusted depending on BMI;

- prevention of thromboembolic complications should begin in the preoperative period and continue during and after the operation and include drug therapy, compression stockings, LCD apparatus, special soft mattresses, massage cuffs on the lower extremities and, if necessary, temporary filters of the lower vena cava. Of the 652 patients operated on for morbid obesity, temporary intracaval filters ("Tulip") were installed in 27 patients with a DVT history and increased risk of thromboembolism. 
That made it possible for us to perform surgery in a safe mode and remove the filters within 3 weeks after surgery ${ }^{32}$;

- prevention of infectious complications should be carried out before, during and after the operation, using antiseptics and broad-spectrum antibiotics, as infectious complications can easily occur in patients with obesity and diabetes. For the prevention of infectious complications in this category of patients, we have created a device for retraction and protection of the surgical wound (Patent No. 49955, 2010) ${ }^{33}$, which significantly reduced the number of wound infectious complications.

- stabilization of hemodynamics during surgery may present certain difficulties since most patients with morbid obesity have hypertension;

- long-term presence of a patient with massive obesity on the operating table can lead to prolonged tissue crushing syndrome, rhabdomyolysis and acute renal failure. Monitoring of myoglobin, CPK and renal function, as well as early prevention of these complications is necessary ${ }^{34}$.

- the use of local prolonged analgesia with an elastic On-Q pain Pump balloon (USA) or a microinfusion pump (VOGT, Germany) after bariatric surgery and abdominoplasty reduces the amount of narcotic painkillers in the postoperative period;

- transportation of the patients inside the hospital requires more time, the involvement of more personnel, special devices designed for morbidly obese patients, the mandatory use of adequate monitoring and the availability of emergency kit during transportation.

The effect of morbid obesity on the respiratory system can be of varying severity - from small asymptomatic changes to life-threatening conditions, such as hypoventilation syndrome and respiratory arrest during sleep (sleep apnea). Clarification of the degree of pulmonary dysfunction of the patient is absolutely necessary before surgery and anesthesia ${ }^{35}$.

${ }^{32}$ Halmi D., Kolesnikov E. Preoperative placement of retrievable inferior cava filters in bariatric surgery, Surgery for Obesity and Related Diseases, 2007, Vol. 3, No. 6, 602-605.

${ }^{33}$ Колесников Є.Б., Радзіховський А.П., Крижевський В.В. та ін., Пристрій для рефракції та протекції лапаротомної рани. Патент № 49955, зареєстровано 11.05.2010, UA, A61B 17/00

${ }^{34}$ Halmi D., Kolesnikov E., Duvall D. Risk assessment, prevention and treatment of postoperative rhabdomyolysis in bariatric patients. Surgery for obesity and related diseases, Vol. 1, No.2, May/June 2005, P. 267

${ }^{35}$ Tran D, Halmi D, Kolesnikov E Intussusception following roux-en-y gastric bypass : two case reports ans literature review , 14-th IFSO World Congress, August 26-29, 2009, Paris, France, Obesity Surgery, 19 (8) 2009, 1038-1039; Steeg K.V. Retrograde intussusception following Roux-en-Y gastric bypass Obes Surg. 2006;16: 1101-1103; Halmi D., Anez O., 
Thus, the diagnosis and treatment of obese patients with $\mathrm{ABO}$ is a complex problem requiring a multi-disciplinary approach using all possible resources of both surgery and anesthesiology and intensive care.

Patients with morbid obesity and concomitant $\mathrm{ABO}$ are difficult to treat in the presence of severe intoxication. To improve the results of surgical treatment this kind of patients we developed and implemented detoxification methods in combination with stimulation of intestinal motility, immunocorrection and methods of early restoration of intestinal motility.

The technique includes repeated sessions of membrane plasmapheresis in combination with methods of stimulating intestinal motility with a pulsed magnetic field. For these patients we use the Almag-01 and Almag 02 apparatus with pulsed magnetic field through the anterior abdominal wall. In the postoperative period this technique is used in combination with the administration of enterosorbents. The effect was expressed with detoxification and more rapid restoration of intestinal motility in the postoperative period.

\section{CONCLUSIONS}

The diagnosis and treatment of morbidly obese patients with $\mathrm{ABO}$ is a complex problem requiring a multi-disciplinary approach using all possible resources of surgery, anesthesiology and intensive care. When carrying out general anesthesia and operations for $\mathrm{ABO}$ in patients with morbid obesity we need to take into consideration hemodynamic changes, respiratory disorders, level of glucosemia, acidosis, endogen intoxication, impaired renal function, possibility of thromboembolic complications, rhabdomyolysis and other factors to achieve more rapid restoration of intestinal motility and quicker patients recovery in postoperative period.

\section{SUMMARY}

Obesity is a chronic genetically determined, multifactorial, lifethreatening disease rapidly spreading around the world. High BMI with excess of body fat, the presence and severity of the metabolic syndrome determine the severity of the course of the disease, when combined with intestinal obstruction. This group of patients causes difficulties at all stages of diagnosis and medical care. The effect of morbid obesity on the respiratory system can be of varying severity - from small asymptomatic changes to life-threatening conditions, such as hypoventilation syndrome

Kolesnikov E., Roux -en-Y gastric bypass: gastro-jejunostomy technique and complications. Obesity Surgery, 16, (4) 2006, 404-405; $2^{\text {nd }}$ European IFSO Congress of Bariatric and Plastic Surgery, April 27-29, 2006, Lyon, France. 
and/or respiratory arrest. Patients with morbid obesity and concomitant $\mathrm{ABO}$ are difficult to treat in the presence of severe intoxication. To improve the results of surgical treatment this kind of patients we developed and implemented detoxification methods in combination with stimulation of intestinal motility, immunocorrection and methods of early restoration of intestinal motility. The technique includes repeated sessions of membrane plasmapheresis in combination with methods of stimulating intestinal motility with a pulsed magnetic field.

\section{REFERENCES}

1. Felsher J.Brodsky J., Brody F. Small bowel obstruction after laparoscopic Roux-en-Y gastric bypass. Surg. 2003; 134:501-5.

2. Nguyen N.T., Huerta S., Gelfand D.et al. Bowel obstruction after laparoscopic Roux-en-Y gastric bypass. Obes. Surg., 2004;(14):190-196.

3. Луценко Н.С. Акушерские аспекты ожирения, Запорожье : Просвіта, 2000.160 с. С. $6-9$.

4. Каминский А.В. Методы коррекции избыточной массы тела и ожирения. Здоров’я Украӥни. № 112, II-2005 г. С. 34.

5. Cowan G, Hiller M. L., Martin L.F. Reoperative obesity surgery. In Obesity surgery, McGraw Hill Comp. 2004. P. 301-334.

6. Yu J. et al. Roux-en-Y Gastric Bypass , Radiology 2004; (231): 753-760.

7. Champion J.K., William M., Small bowel obstruction and internal hernias after laparoscopic Roux-en-Y gastric bypass. Obes surg. 2003; 13: 596-600

8. Higa K.D., Ho T, Boone K.B. Internal hernias after laparoscopic Roux-en-Y gastric bypass: incidence, treatment and prevention. Obes Surg., 2003; 13: 350-4

9. Tucker O.N, Escalante-Tattersfield T., Szomstein S., Rosenthal R. The ABC System: A Simplified Classification System for Small Bowel Obstruction After Laparoscopic Roux-en-Y Gastric Bypass Obesity Surgery 2007; (17): 1549-1554.

10. Ukleja A., Stone R. L. Medical and gastroenterologic management of the post-bariatric surgery patient. J Clin Gastroenterol 2004; 38(4): 312-21.

11. Gumbs A.A., Duffy A.J., Chandwani R. et al. Jejuno-jejunal anastomotic obstruction following laparoscopic gastric bypass due to nonabsorbable suture: a report of seven cases. Obes. Surg. 2006;16: 12-15.

12. Madan A.K., Lo Menzo E et al. Internal hernias, non-closure of mesenteric defects laparoscopic Roux-en-Y gastric bypass. Obes Surg., 2009; 19(5):549-52. 
13. Facchiano E., Iannelli A., Gugenheim J. Et al. Internal hernias and non-closure of mesenteric defects during laparoscopic Roux-en-Y gastric bypass. Obes Surg, 2010;20:676-678.

14. Husain S, Ahmed AR, Johnson J, Boss T, O'Malley W Small-bowel obstruction after laparoscopic Roux-en-Y gastric bypass: etiology, diagnosis, and management. Arch Surg. 2007 Oct;142(10):988-93.

15. Nandipati KC, Lin E, Husain F, Srinivasan J, Sweeney JF, Davis SS. Counterclockwise rotation of Roux-en-Y limb significantly reduces internal herniation in laparoscopic Roux-en-Y gastric bypass (LRYGB). J Gastrointest Surg. 2012 Apr;16(4):675-81. Epub 2012 Feb 7.

16. Halmi D., Anez O., Kolesnikov E. Mini-open roux-en-Y gastric bypass: surgical complications and difficulties. XXXIV World Congress of the International College of Surgeons, October 2004, Quito, Ecuador. International Proceedings, MEDIMOND, Italy, 2004. P. 109-113.

17. Halmi D, Anez O, Kolesnikov E Mini-open Roux-en-Y gastric bypass as the operation of choice for the majority of morbidly obese patients. Obesity surgery, 15, 2005. P. 960-6.

18. Tran D, Halmi D, Kolesnikov E Intussusception following roux-en-y gastric bypass : two case reports ans literature review, 14-th IFSO World Congress, August 26-29, 2009, Paris, France, Obesity Surgery, 19 (8) 2009, 1038-1039.

19. Steeg K.V. Retrograde intussusception following Roux-en-Y gastric bypass Obes Surg. 2006;16: 1101-1103.

20. Halmi D., Anez O., Kolesnikov E., Roux -en-Y gastric bypass: gastro-jejunostomy technique and complications. Obesity Surgery, 16, (4) 2006, 404-405; $2^{\text {nd }}$ European IFSO Congress of Bariatric and Plastic Surgery, April 27-29, 2006, Lyon, France.

21. Halmi D., Anez O., Kolesnikov E. Mini-open Roux-en-Y gastric bypass: 1200 anastomoses without leak. Obesity Surgery, 14, 8. 2004. P. 900-901.

22. Petersen W. Ueber darmveschlingung nach der gastro-enterostomie. Arch Klin Chir. 1900; 62:94-114.

23. MacGregor AMC Small bowel obstruction following gastric bypass. Obes Surg., 1992; 2:333-9.

24. Helling T.S. The Lethality of Obstructing Hematoma at the Jejunojejunostomy following Roux-en-Y Gastric Bypass. Obesity Surgery 2005; (15): 290-293

25. Halmi D., Kolesnikov E. Preoperative placement of retrievable inferior cava filters in bariatric surgery, Surgery for Obesity and Related Diseases. 2007. Vol. 3. No. 6. P. 602-605. 
26. Колесников Є.Б., Радзіховський А.П., Крижевський В.В. та ін. Пристрій для рефракції та протекції лапаротомної рани. Патент № 49955, зареєстровано 11.05.2010, UA, А61B 17/00.

27. Halmi D., Kolesnikov E., Duvall D. Risk assessment, prevention and treatment of postoperative rhabdomyolysis in bariatric patients. Surgery for obesity and related diseases, Vol. 1, No.2, May/June 2005. P. 267.

\section{Information about authors:} Kolesnikov E. B., Doctor of Medical Sciences, Professor of the Department of General and Emergency Sciences Shupyk National Medical Academy of Postgraduate Education 9, Dorogozhyzkaja str., Kyiv, Ukraine

Kryzhevsky V. V., Doctor of Medical Sciences, Professor, Head of the Department of General and Emergency Sciences Shupyk National Medical Academy of Postgraduate Education

9, Dorogozhyzkaja str., Kyiv, Ukraine 